\title{
Growth and Water Use of Petunia as Affected by Substrate Water Content and Daily Light Integral
}

\author{
Marc W. Van Iersel ${ }^{1}$ and Sue Dove \\ Department of Horticulture, University of Georgia, 1111 Miller Plant \\ Sciences Building, Athens, GA 30602
}

\author{
Jong-Goo Kang \\ Department of Horticulture, Sunchon National University, 315 Maegok-Dong, \\ Sunchon, Chonnam 540-742, South Korea
}

\section{Stephanie E. Burnett \\ Department of Plant, Soil, and Environmental Sciences, University of Maine, 5722 Deering Hall, Orono, ME 04469}

Additional index words. capacitance sensors, evapotranspiration, greenhouse irrigation, leaching, soil moisture sensors, volumetric water content, water potential

\begin{abstract}
More efficient irrigation practices are needed in ornamental plant production to reduce the amount of water used for production as well as runoff of fertilizers and pesticides. The objective of this study was to determine how different substrate volumetric water contents $(\theta)$ affected petunia (Petunia $\times$ hybrida) growth and to quantify the daily water use of the plants. A soil moisture sensor-controlled irrigation system was used to maintain $\theta$ within $\approx 0.02 \mathrm{~m}^{3} \cdot \mathrm{m}^{-3}$ of the $\theta$ threshold values for irrigation, which ranged from 0.05 to $0.40 \mathrm{~m}^{3} \cdot \mathrm{m}^{-3}$. Shoot dry weight increased as the $\theta$ threshold increased from 0.05 to $0.25 \mathrm{~m}^{3} \cdot \mathrm{m}^{-3}$ and was correlated with the total amount of irrigation water applied over the 3-week course of the experiment. The daily water use of the petunias grown with a $\theta$ threshold of $0.40 \mathrm{~m}^{3} \cdot \mathrm{m}^{-3}$ was 12 to $44 \mathrm{~mL} /$ plant and was positively correlated with both plant age and daily light integral. Lower $\theta$ thresholds resulted in a decrease in both leaf water $(\psi)$ and osmotic potential $\left(\psi_{\mathrm{S}}\right)$. A decrease in turgor pressure $(P)$ at lower $\theta$ was seen at 11, but not 20 days after the start of the treatments. There were no significant effects of $\theta$ on $\psi, \psi_{\mathrm{S}}$, or $\mathrm{P}$ on fully rehydrated plants at the end of the study. Plants were able to survive and grow at all $\theta \mathrm{s}$, although water at a $\theta$ less than $0.20 \mathrm{~m}^{3} \cdot \mathrm{m}^{-3}$ is generally considered to be unavailable to the plants. Results show that it is possible to automatically irrigate plants with the use of soil moisture sensors, and this approach to irrigation may have applications in controlling the growth of ornamental plants.
\end{abstract}

Managing global water resources is one of the most pressing challenges of the 21 st century. Population growth and increased urbanization have increased competition for water by agricultural, industrial, and domestic users. Agricultural water use in many areas of the world is not sustainable (Jury and Vaux, 2005). To meet the long-term needs of the world's population, it is crucial that the efficiency of agricultural water use is increased (Howell, 2001) and science and technology must play an important role in addressing problems arising from a global water shortage.

The greenhouse industry is not immune from these issues, and improving irrigation efficiency must play an important role in making greenhouse production more sustainable. Various U.S. states have legislation regulat-

\footnotetext{
Received for publication 29 Oct. 2009. Accepted for publication 17 Dec. 2009.

We thank the Fred C. Gloeckner Foundation for their financial support and Fafard, Inc. for donation of the substrate.

${ }^{1}$ To whom reprint requests should be addressed; e-mailmvanier@uga.edu.
}

ing agricultural water use and quality. Some legislation requires greenhouses and nurseries to develop nutrient management plans describing efforts to reduce nonpoint source pollution (Lea-Cox and Ross, 2001).

Good irrigation management is an important best management practice in ornamental crop production, reducing runoff of nutrientand pesticide-rich water from production sites (Briggs et al., 1998; Lea-Cox and Ross, 2001; Tyler et al., 1996). Better control of irrigation can have other benefits as well: better plant quality, more compact plants (Burnett and van Iersel, 2008), and reduced damage from root pathogens (Powell and Lindquist, 1997). In addition, more efficient irrigation can have direct economic benefits, because less electricity or fuel is needed to pump the irrigation water.

A promising approach for improving irrigation management sustainability is the use of real-time sensing technology to detect the water status of the plants or soil/substrate and to use those measurements to control irrigation. For example, Prenger et al. (2005) used infrared (IR) thermometry to determine the canopy temperature of New Guinea impa- tiens (Impatiens $\times$ hawkeri), which was used for calculations of a crop water stress index. This index was then used to automatically turn irrigation on and off. The crop water stress index is a sensitive method to detect drought stress and may be able to detect the onset of drought stress 1 to $2 \mathrm{~d}$ before visible symptoms occur (Blom-Zandstra and Metselaar, 2006; Kacira et al., 2002). Drawbacks of using sensors to detect plant stress for irrigation control are that such methods do not indicate how much water should be applied and that plant water status is very sensitive to changing environmental conditions, radiation in particular (Jones, 2004). For example, Blom-Zandstra and Metselaar (2006) reported that IR sensors did not accurately detect drought stress on overcast days. In addition, measurements of crop water status may give a good indication of the onset of drought stress but are less well suited to preventing drought stress (i.e., irrigation generally occurs after the initial symptoms of drought stress have been detected). An alternative to measuring the water status of the plants is to control irrigation based on measurements of soil water content. This approach has the advantage that it is readily applied and allows for easy automation (Jones, 2004). Jones (2007) concluded that soil water content is the most valuable measure of plant or soil water status for purposes of irrigation scheduling.

We have developed an automated irrigation system that measures substrate volumetric water contents $(\theta)$ in multiple containers and irrigates them based on containerspecific $\theta$ thresholds. This irrigation system can maintain $\theta$ within a narrow range and automatically adjusts irrigation as plants get larger or environmental conditions change (Nemali and van Iersel, 2006). We have since modified this irrigation system to allow for precise determination of the daily amount of water applied to each container (see subsequently for details).

This new irrigation system allows for maintenance of $\theta$ levels and thus makes it possible to evaluate whole plant physiology and morphology under continuous drought stress (Nemali and van Iersel, 2008). Burnett and van Iersel (2008) used this irrigation system to quantify the effects of different $\theta$ s on the growth and morphology of gaura (Gaura lindheimeri). Stem length and the number of branches were reduced, whereas water use efficiency was increased at lower $\theta$ s. By comparison, in other drought physiology studies, substrates are allowed to dry to a certain $\theta$ and are then rewatered. In one such study, Niu et al. (2006) dried substrates to a $\theta$ of $\approx 0.18 \mathrm{~m}^{3} \cdot \mathrm{m}^{-3}$ after which the plants were rewatered. They reported that responses of six different bedding plant species, including petunia, to drought were speciesspecific (Niu et al., 2006). Drought stress reduced petunia dry weight and petunia leaf photosynthesis declined as $\theta$ decreased from 0.26 to $0.07 \mathrm{~m}^{3} \cdot \mathrm{m}^{-3}$. Niu et al. (2006) also found that, among the six species tested, petunia was the most sensitive to drought stress. 
Plant responses to such cyclic drought stresses imposed in previous studies may differ from responses to a continuous drought at stable $\theta$ s. Therefore, the objectives of this study were to 1) determine the effects of different $\theta \mathrm{s}$ on the growth and water relations of petunia (Petunia $\times$ hybrida); and 2) to quantify the daily water use of petunias as they develop from seedlings to salable plants.

\section{Materials and Methods}

Plant material and growing conditions. Opaque containers $(30 \mathrm{~cm} \times 46 \mathrm{~cm} \times 17 \mathrm{~cm})$ with drainage holes in the bottom were filled with $12 \mathrm{~L}$ of a loosely packed peat $(60 \%)$ perlite $(40 \%)$ substrate (Fafard 2P; Fafard, Agawam, MA). After watering in, the substrate volume was $\approx 10 \mathrm{~L} /$ container. The initial substrate solution electrical conductivity (EC) was $3.4 \mathrm{dS} \cdot \mathrm{m}^{-1}$ as measured with an in situ EC sensor (SigmaProbe; Delta T Devices, Burwell, U.K.). Twenty-four petunia 'Velvet Carpet' seedlings grown in 512-cell plug flats were transplanted into each container and watered in. The substrate was wellwatered during the first $9 \mathrm{~d}$ after transplanting to allow the seedlings to establish. At each irrigation throughout this study, plants were watered with a water-soluble fertilizer (20N-4.4P-16.6K; Peters 20-10-20 Peat-lite special; The Scotts Co., Marysville, $\mathrm{OH}$ ) solution at a nitrogen concentration of 200 $\mathrm{mg} \cdot \mathrm{L}^{-1}$ using a fertilizer injector (A30; Dosmatic, Carrollton, TX). The daily maximum and minimum temperatures in the greenhouse averaged $30.3 \pm 2.5$ and $21.8 \pm 0.9^{\circ} \mathrm{C}$, whereas the daily light integral inside the greenhouse averaged $16.8 \pm 4.9 \mathrm{~mol} \cdot \mathrm{m}^{-2} \cdot \mathrm{d}^{-1}$ (means $\pm \mathrm{SD}$ ). Temperature and relative humidity were measured using a humidity and temperature probe (HTO-45; Rotronic, Huntington, NY) and photosynthetic photon flux $(P P F)$ for daily light integral (DLI) calculations was measured with a quantum sensor (QSO-sun; Apogee Instruments, Logan, UT).

Treatments. After plants were established, irrigation was controlled by an automated irrigation controller similar to the one described by Nemali and van Iersel (2006). Two capacitance sensors (EC-5; Decagon, Pullman, WA) were inserted into the substrate in each container at an $\approx 45^{\circ}$ angle with the thin edges of the sensors facing to top and bottom of the containers. The sensors were connected to a multiplexer (AM25T; Campbell Scientific, Logan, UT), which in turn was connected to a data logger (CR10; Campbell Scientific), which measured the 32 soil moisture sensors (two sensors in 16 containers) every $20 \mathrm{~min}$. Voltage readings from the soil moisture sensors were converted to $\theta\left(\mathrm{m}^{3} \cdot \mathrm{m}^{-3}\right)$ using our own substrate-specific calibration $(\theta=$ voltage $\times 1.7647$ to 0.4745 , $\left.r^{2}=0.95\right)$ determined using the procedure of Nemali et al. (2007). The readings from the two sensors in each container were then averaged, and the data logger subsequently compared the average $\theta$ in each container with the $\theta$ threshold for that particular container. As soon as the average $\theta$ in a container dropped below the threshold for irrigation, the data logger sent a signal to a relay driver (SDM16AC/DC controller; Campbell Scientific), which opened a solenoid valve (X13551-72; Dayton Electric Co., Niles, IL) for $1 \mathrm{~min}$.

Each container was watered with two modified dribble rings (Dramm, Manitowoc, WI), which had been shortened to have a diameter of $12 \mathrm{~cm}$ with five emitter holes per ring. The dribble rings were connected to pressure-compensated drip emitters (2 LPH; Netafim USA, Fresno, CA) with an average flow rate of $31.3 \mathrm{~mL} \cdot \mathrm{min}^{-1}$. Because there were two dribble rings per container, $\approx 63 \mathrm{~mL}$ of fertilizer solution was added to a container each time that container was irrigated. The flow rate for each dribble ring was determined individually to allow for accurate calculations of how much water was applied to the individual containers. Irrigation thresholds were $\theta$ values of $0.05,0.10,0.15,0.20$, $0.25,0.30,0.35$, and $0.40 \mathrm{~m}^{3} \cdot \mathrm{m}^{-3}$.

Data collection. In addition to measuring $\theta$ and controlling irrigation, the data logger stored the $\theta$ readings from each sensor every $2 \mathrm{~h}$ and counted the number of times each container was irrigated. This allowed us to calculate the number of irrigations each container received each day and thus the daily irrigation volume.

Leaf water $(\psi)$, osmotic $\left(\psi_{\mathrm{S}}\right)$, and turgor potential $(\mathrm{P})$ were measured three times during the experiment at 11,20 , and $22 \mathrm{~d}$ after the start of the irrigation treatments. On Days 11 and 20, leaf discs were sampled within $1 \mathrm{~h}$ of solar noon using leaf cutter psychrometers (84-2VC; JRD Merrill Specialty Equipment, Logan, UT). A leaf disc with a $5.5-\mathrm{mm}$ diameter was cut from a fully expanded leaf using the sharp edge of the psychrometer. The psychrometer was then sealed within $5 \mathrm{~s}$ to prevent water loss from the sample. On Day 22, the experiment was ended and psychrometer measurements were taken after the containers had been watered to container capacity. The plants were allowed to hydrate fully overnight in a dark and humid environment. Samples were collected the next morning while plants were still in the dark. After sampling, the psychrometers were placed in a $25{ }^{\circ} \mathrm{C}$ water bath for $4 \mathrm{~h}$, after which the psychrometers were measured using a microvolt meter (JRD Merrill Specialty Equipment). After $\psi$ had been measured, the psychrometers were placed in a freezer overnight to disrupt the cell membranes. Subsequently, psychrometers were placed back in the $25^{\circ} \mathrm{C}$ water bath for $4 \mathrm{~h}$ after which $\psi_{\mathrm{S}}$ was measured. Finally, $\mathrm{P}$ was calculated as $\psi-\psi_{\mathrm{s}}$.

At the end of the experiment, the shoots were cut off at the substrate surface and dried for 1 week at $80{ }^{\circ} \mathrm{C}$, after which their dry weight was determined.

Experimental design and data analysis. The experimental design was a randomized complete block with eight treatments $(\theta$ thresholds) and two replications. The data were analyzed using linear, quadratic, and nonlinear regression analysis. Because there was a day $\times \theta$ threshold interaction for the psychrometer data, those data were analyzed by day. Initially, the psychrometer data were analyzed using linear and quadratic regression. When quadratic regression indicated a nonlinear response, an exponential rise to a maximum was fitted, because it resulted in a substantially better fit than a quadratic curve. Curve fitting was done using SAS (SAS Institute, Cary, NC) and SigmaPlot (Systat, San Jose, CA). To quantify the effects of plant age and DLI on daily irrigation volume, multiple regression was performed in Excel (Microsoft, Redmond, WA) to fit the following equation: daily water use $=a_{0}+a_{1} \times$ DLI $+a_{2} \times$ time, in which $\mathrm{a}_{0}, \mathrm{a}_{1}$, and $\mathrm{a}_{2}$ are regression coefficients and time is the number of days since the start of the treatments. Only the data from the treatment with a $\theta$ threshold of $0.40 \mathrm{~m}^{3} \cdot \mathrm{m}^{-3}$ were used because this treatment had the highest water use and the regression equation therefore describes the maximum amount of water that is used by these plants.

\section{Results and Discussion}

Substrate water content. The automated irrigation system generally was able to maintain $\theta$ close to the $\theta$ threshold (Fig. 1). Likewise, Nemali and van Iersel (2006) previously reported that a similar irrigation system was able to maintain stable $\theta$ levels despite increases in plant size and large fluctuations in DLI and relative humidity. Control of $\theta$ was better than in our previous study with gaura (Burnett and van Iersel, 2008), because smaller volumes of water were applied at each irrigation $(63 \mathrm{~mL}$ in this study versus $340 \mathrm{~mL}$ in the study with gaura). It took $9 \mathrm{~d}$ from the start of the treatments for the substrate to dry out to the lowest $\theta$ threshold $\left(0.05 \mathrm{~m}^{3} \cdot \mathrm{m}^{-3}\right)$. From Day 13 to $15, \theta$ in one of the two plots with $\theta$ thresholds of $0.30 \mathrm{~m}^{3} \cdot \mathrm{m}^{-3}$ greatly exceeded the threshold. This was caused by heavy rain on Day 13 , which caused water to leak through the greenhouse glazing and drip into that particular tray. Fluctuations in $\theta$ were greater at low $\theta$ thresholds than at higher thresholds (Fig. 1). This is consistent with previous findings (Nemali and van Iersel, 2006) and may be the result of the decreased hydraulic conductivity of peat-based substrates at lower water contents (Naasz et al., 2005). This decrease in hydraulic conductivity slows water movement in the substrate and potentially results in a less uniform water distribution, thus increasing variability.

Irrigation volume. The total amount of water applied during the treatment period increased linearly with increasing $\theta$, from $\approx 80 \mathrm{~mL} /$ plant in the $0.05 \mathrm{~m}^{3} \cdot \mathrm{m}^{-3}$ treatment to $610 \mathrm{~mL} /$ plant in the $0.40 \mathrm{~m}^{3} \cdot \mathrm{m}^{-3}$ treatment (Fig. 2).Burnett and van Iersel (2008), Kim and van Iersel (2009), and Nemali and van Iersel (2006) also reported that the total irrigation volume increases with increasing $\theta$ threshold, although not necessarily linearly. None of the applied irrigation water leached from the containers in this experiment, whereas Burnett and van Iersel (2008) reported leaching of at 


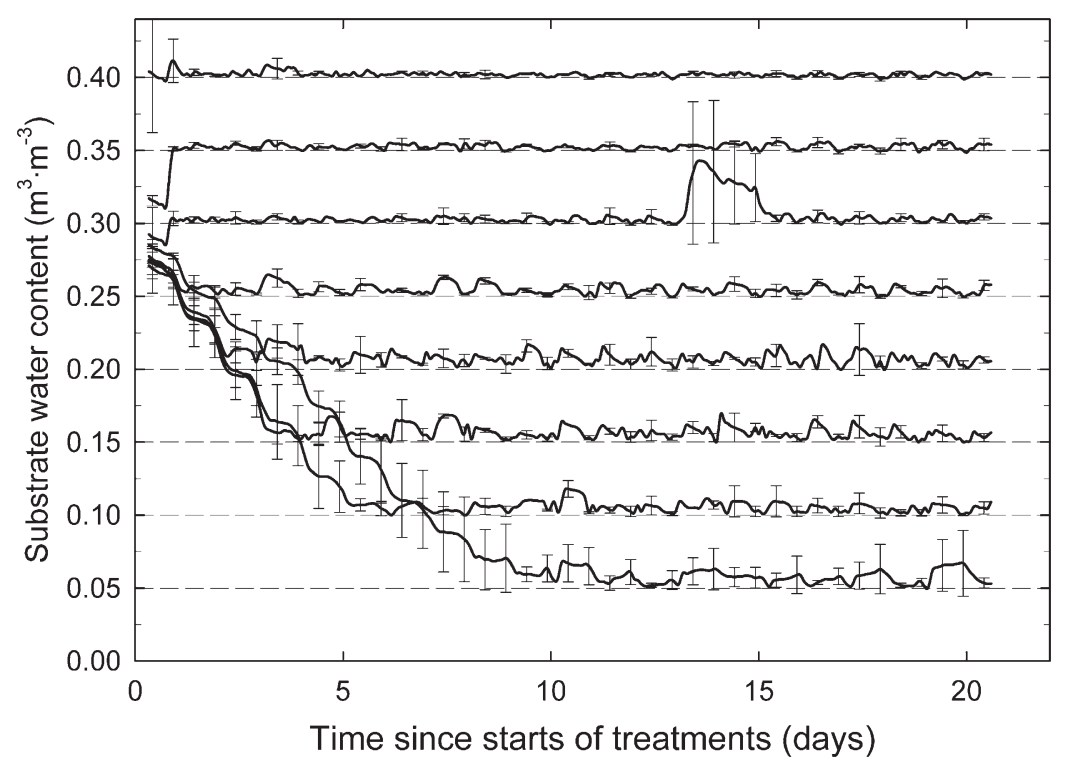

Fig. 1. Average substrate volumetric water content $(\theta)$ as maintained by a soil moisture sensor-controlled automated irrigation system. Dashed lines indicate the $\theta$ threshold at which the containers in the various treatments were irrigated. Selected error bars (every half day) indicate the mean $\pm \operatorname{SD}(n=2)$. Error bars that are not visible (e.g., in the $0.40 \mathrm{~m}^{3} \cdot \mathrm{m}^{-3}$ treatment) indicate very small sDs.

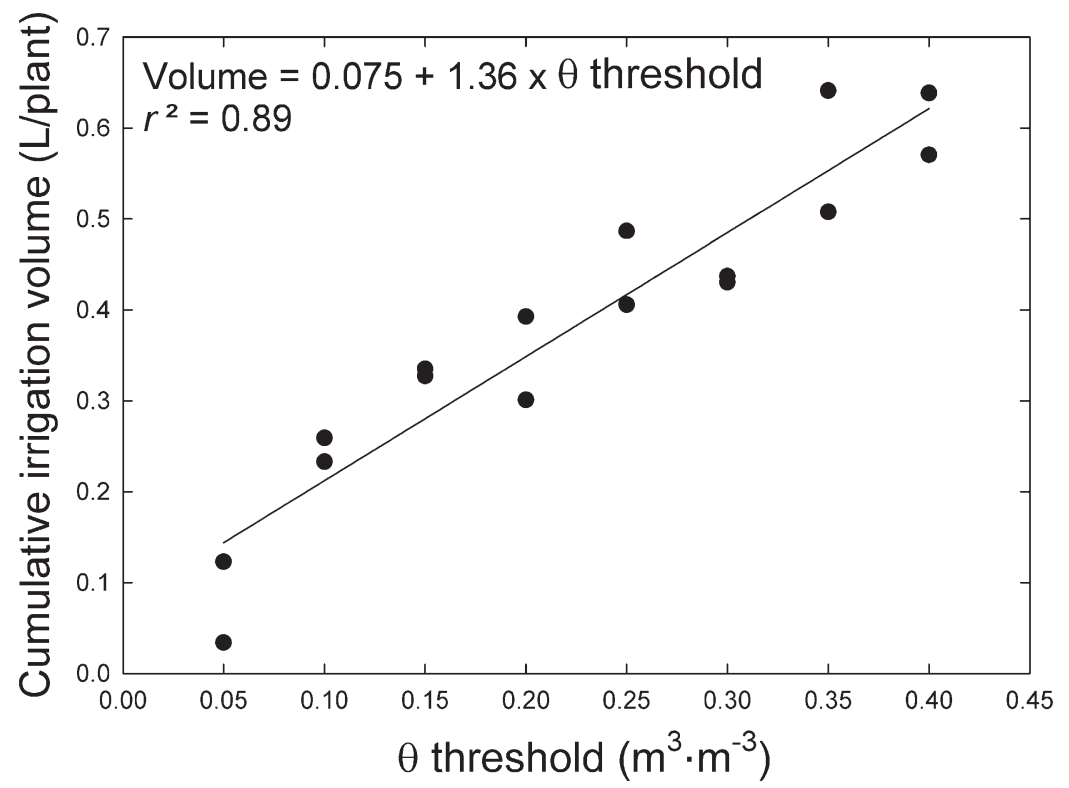

Fig. 2. Cumulative irrigation volume, from treatment initiation until the termination of the experiment (22 d), as a function of the substrate volumetric water content $(\theta)$ threshold at which plants were irrigated.

least some of the applied water at $\theta$ thresholds of $0.40 \mathrm{~m}^{3} \cdot \mathrm{m}^{-3}$ or higher in a similar experiment with gaura. Although substrate volume was similar in the current study and the gaura experiment, Burnett and van Iersel (2008) applied substantially more water at each irrigation event. The lower irrigation volume in the current study resulted in more frequent irrigations with smaller amounts of water, better control of $\theta$ (generally within $0.02 \mathrm{~m}^{3} \cdot \mathrm{m}^{-3}$ of the threshold), and eliminated leaching.

The daily irrigation volume in the 0.40 $\mathrm{m}^{3} \cdot \mathrm{m}^{-3}$ treatment was 12 to $20 \mathrm{~mL} /$ plant during the first week and increased to a maximum of $44 \mathrm{~mL} /$ plant near the end of the experiment. As was the case with the total amount of water applied during the entire treatment period (Fig. 2), the daily irrigation volume increased with increasing $\theta$ thresholds (Fig. 3, bottom). In addition, irrigation volume in all treatments tended to increase during the experiment, likely as a result of increased water use by larger plants. However, there were large daily fluctuations in the amount of irrigation water applied, which were correlated with changes in DLI. For example, irrigation volumes were low on Days 7 and 14, when DLI was low (Fig. 3). Using only the data from the $0.40 \mathrm{~m}^{3} \cdot \mathrm{m}^{-3}$ treatment for multiple regression confirmed that both time and DLI were positively correlated with daily irrigation volume (Fig.
4). The regression equation [daily irrigation volume $(\mathrm{mL} / \mathrm{plant})=-7.15+1.14 \times \mathrm{DLI}+$ $1.54 \times$ time] indicates that water use of the plants increased by $1.54 \mathrm{~mL} \cdot \mathrm{d}^{-1}$ over the course of the study and by $1.14 \mathrm{~mL} \cdot \mathrm{d}^{-1}$ for each additional $\mathrm{mol} \cdot \mathrm{m}^{-2} \cdot \mathrm{d}^{-1}$ of $P P F$. This simple model, based solely on time and DLI, explained much of the variation in the daily irrigation volume $\left(r^{2}=0.79\right.$; Fig. 4). This suggests that it may be possible to use relatively simple models to predict the water needs of floricultural crops. Similarly, daily water use of abutilon (Abutilon $\times$ hybridum) and lantana (Lantana camara) was strongly correlated with plant age and DLI (Kim and van Iersel, 2009). In Kim and van Iersel's (2009) study, the daily maximum vapor pressure deficit also was correlated with daily water use, although not as strongly as either DLI or plant age. Overall, daily water use of abutilon and lantana could be accurately described as a function of time, DLI, and vapor pressure deficit $\left(r^{2}=0.94\right.$; Kim and van Iersel, 2009). However, in both Kim and van Iersel (2009) and the current study, the data reflect the actual irrigation volume versus the predicted irrigation volume of the same plants (Fig. 4); i.e., the predictions of daily water needs were not evaluated with an independent data set. For a more definitive evaluation of simple regression models to predict plant water needs, it will be necessary to grow plants for model development separate from those to be used for model evaluation to assure that the two data sets are independent (Wallach, 2006). Until such studies have been conducted, simple descriptive models like this should not be used to automate greenhouse irrigation.

Shoot dry weight. The $\theta$ threshold not only affected the amount of water that was applied, but plant growth as well. There was a quadratic relationship between the $\theta$ threshold and shoot dry weight; as the threshold increased from 0.05 to $0.25 \mathrm{~m}^{3} \cdot \mathrm{m}^{-3}$, shoot dry weight increased from $\approx 0.7 \mathrm{~g} / \mathrm{plant}$ to $1.7 \mathrm{~g} / \mathrm{plant}$. There was little additional increase in dry weight as the $\theta$ threshold further increased to $0.40 \mathrm{~m}^{3} \cdot \mathrm{m}^{-3}$ (Fig. 5, left). There were linear increases in shoot dry weight of gaura (Burnett and van Iersel (2008), abutilon, and lantana (Kim and van Iersel, 2009) as the $\theta$ threshold increased. Starman and Lombardini (2006) found that plant growth and development of four herbaceous perennials continued at a $\theta$ of $0.13 \mathrm{~m}^{3} \cdot \mathrm{m}^{-3}$. Our findings indicate that plants can survive, and exhibited some growth, at even lower $\theta$. Niu et al. (2007) used a different irrigation approach to determine the effects of $\theta$ on growth and cut flower production of Big Bend bluebonnet (Lupinus havardii). They allowed $\theta$ to decrease to anywhere from 0.12 to $0.33 \mathrm{~m}^{3} \cdot \mathrm{m}^{-3}$ before the plants were irrigated and found that allowing the substrate to dry out to $\theta$ of 0.12 or $0.15 \mathrm{~m}^{3} \cdot \mathrm{m}^{-3}$ reduced the dry weight and cut flower yield of the plants. Petunia exposed to cyclic drought stress also had reduced shoot dry weight if the substrate was allowed to dry out to $\approx 0.18 \mathrm{~m}^{3} \cdot \mathrm{m}^{-3}$ as compared with $\approx 0.25 \mathrm{~m}^{3} \cdot \mathrm{m}^{-3}$ before plants were irrigated (Niu et al., 2007). 


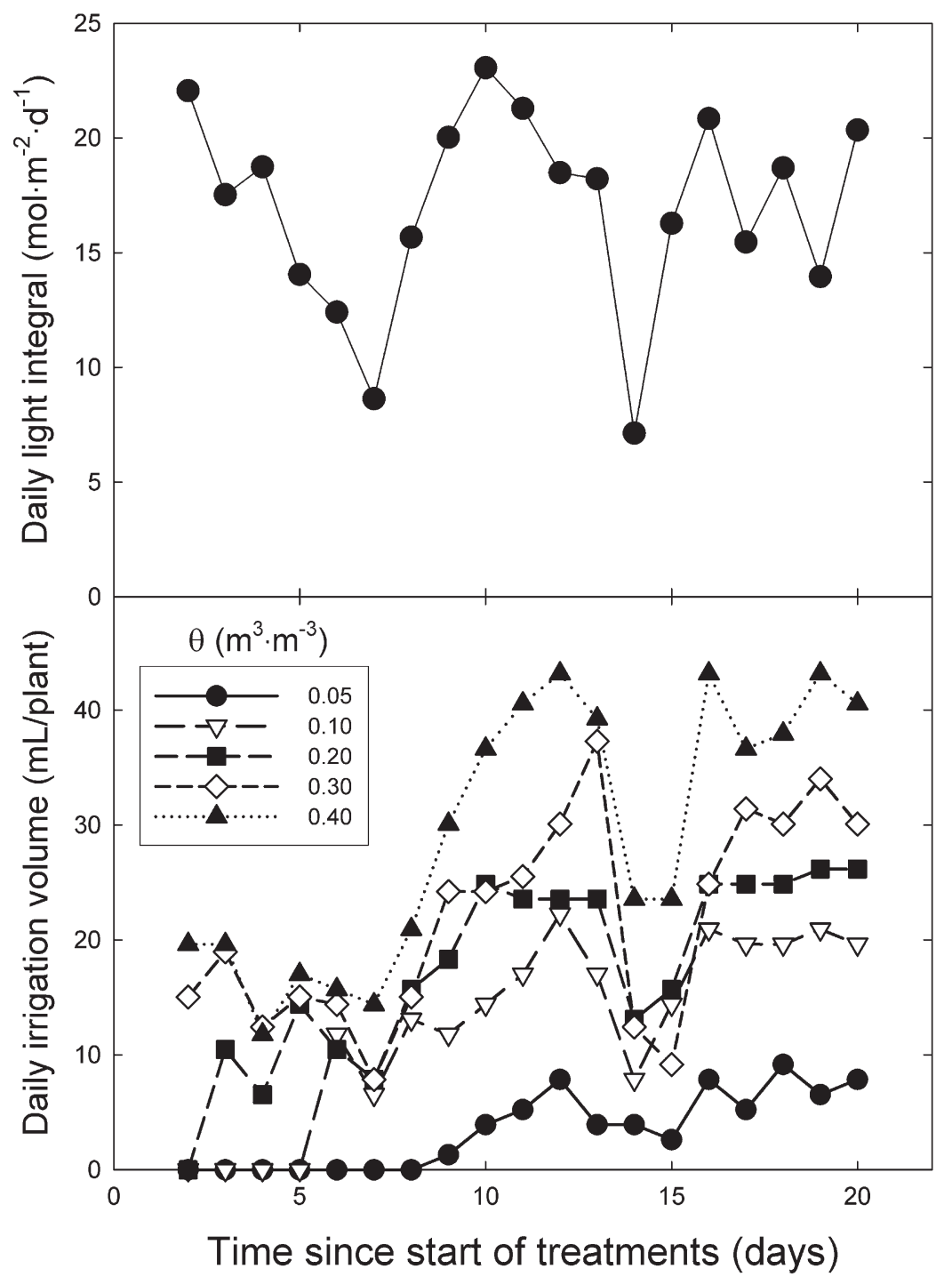

Fig. 3. Daily light integral (top) and daily irrigation volume (bottom) for petunias irrigated with a soil moisture sensor-controlled irrigation system. Substrate volumetric water content $(\theta)$ thresholds ranged from 0.05 to $0.40 \mathrm{~m}^{3} \cdot \mathrm{m}^{-3}$. Daily irrigation volumes of only five of eight treatments are shown for clarity. Note that days with a low daily light integral (e.g., Days 7 and 14) generally result in a low irrigation volume.

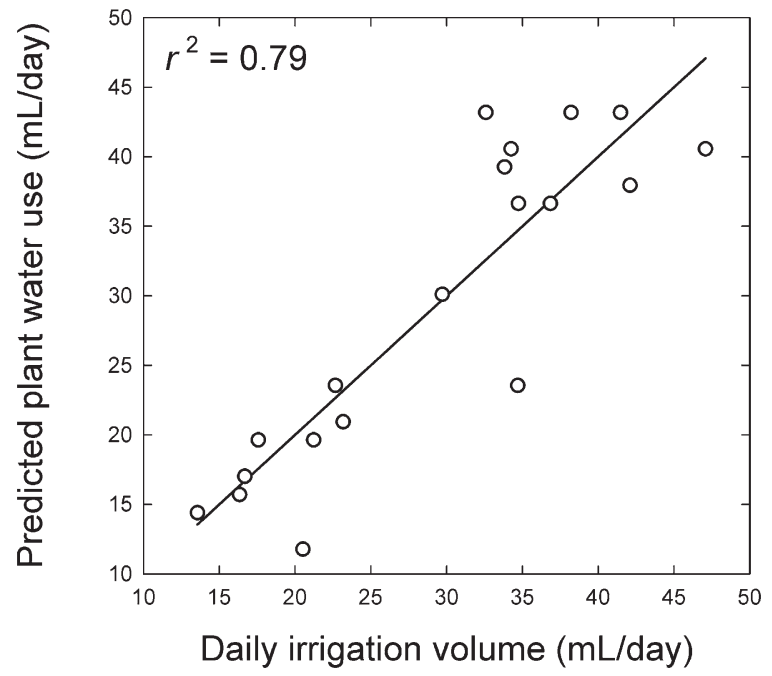

Fig. 4. The measured daily irrigation volume when the substrate water content was maintained at 0.40 $\mathrm{m}^{3} \cdot \mathrm{m}^{-3}$ versus the predicted plant water use. Water use was predicted as a function of plant age (days since the start of the experiment) and daily light integral (DLI): water use $=-7.15+1.14 \times$ DLI $+1.54 \times$ time. Regression coefficients for both DLI and time were significant at $P<0.005$.
There was a linear relationship between the total irrigation volume and shoot dry weight (Fig. 5, right). The slope of the regression line is a measure of water use efficiency: for every liter of water applied, an additional $2.54 \mathrm{~g}$ of shoot dry weight was produced; conversely, $394 \mathrm{~mL}$ of water was used for the production of $1 \mathrm{~g}$ shoot dry mass. Unlike most measures of water use efficiency, the slope of this regression line accounts for both evaporation from the substrate and transpiration from the plants. This water use efficiency is similar to that reported for geraniums (Pelargonium $\times$ hortorum) grown in a greenhouse in Italy during spring (2.2 g. $\left.\mathrm{L}^{-1}\right)$ (Colla et al., 2009). Colla et al. (2009) also found that water use efficiency differed greatly between winter $\left(4.2 \mathrm{~g} \cdot \mathrm{L}^{-1}\right)$ and spring $\left(2.2 \mathrm{~g} \cdot \mathrm{L}^{-1}\right)$ crops, which they attributed to differences in environmental conditions in winter and spring.

The correlation between irrigation volume and shoot dry weight also suggests that applying more than $650 \mathrm{~mL}$ water might have resulted in even higher shoot dry weight. However, extrapolating this curve may not be valid, because factors other than water obviously may limit plant growth. The quadratic relationship between shoot dry weight and $\theta$ threshold suggests that thresholds above 0.40 $\mathrm{m}^{3} \cdot \mathrm{m}^{-3}$ would have resulted in little, if any, additional increase in dry weight.

Based on the visual appearance of these plants, $\theta$ thresholds of $0.10 \mathrm{~m}^{3} \cdot \mathrm{m}^{-3}$ or higher resulted in salable plants, although those grown with $\theta$ thresholds of 0.10 and 0.15 $\mathrm{m}^{3} \cdot \mathrm{m}^{-3}$ were visibly smaller than those grown at higher $\theta$ thresholds. Plants grown at a $\theta$ threshold of $0.05 \mathrm{~m}^{3} \cdot \mathrm{m}^{-3}$ survived but were severely stunted and flowered poorly. Our finding that petunias can be grown with a $\theta$ threshold as low as $0.10 \mathrm{~m}^{3} \cdot \mathrm{m}^{-3}$ is surprising given that substrate water release curves for peat-based substrates suggest that there is little or no plant-available water present in these substrates at a $\theta$ of less than 0.20 to $0.24 \mathrm{~m}^{3} \cdot \mathrm{m}^{-3}$ (Fonteno, 1996; Wallach, 2008). However, substrate water release curves are based on steady-state conditions in the substrate. It is not clear whether such curves can be used to determine water availability in substrates in which plant water uptake and frequent irrigations result in dynamic conditions.

Plant water relations. Responses of leaf water relations to $\theta$ thresholds differed between Days 11 and 20. On Day 11, $\psi$ was consistently higher $(-0.4 \mathrm{MPa})$ than $\psi_{\mathrm{S}}(-0.7$ $\mathrm{MPa})$ at $\theta$ thresholds above $0.10 \mathrm{~m}^{3} \cdot \mathrm{m}^{-3}$, whereas $\psi$ and $\psi_{\mathrm{S}}$ were similar $(-1.3 \mathrm{MPa})$ at a $\theta$ threshold of $0.05 \mathrm{~m}^{3} \cdot \mathrm{m}^{-3}$ (Fig. 6). There was an increase in $\mathrm{P}$ with increasing $\theta$ thresholds. On Day 20, $\psi$ and $\psi_{\text {S }}$ were similar to those on Day 11 at $\theta$ thresholds of 0.10 $\mathrm{m}^{3} \cdot \mathrm{m}^{-3}$ or higher, but there was no steep decline in $\psi$ and $\psi_{\mathrm{S}}$ at a $\theta$ threshold of 0.05 $\mathrm{m}^{3} \cdot \mathrm{m}^{-3}$. There was no effect of $\theta$ threshold on $\mathrm{P}$ on Day 20. The results for Day 20 are similar to those previously reported for vinca with lower $\psi$ and $\psi_{\mathrm{S}}$ with lower $\theta$ thresholds without an effect on P (van Iersel et al., 2007). The $\psi$ of Big Bend bluebonnet 


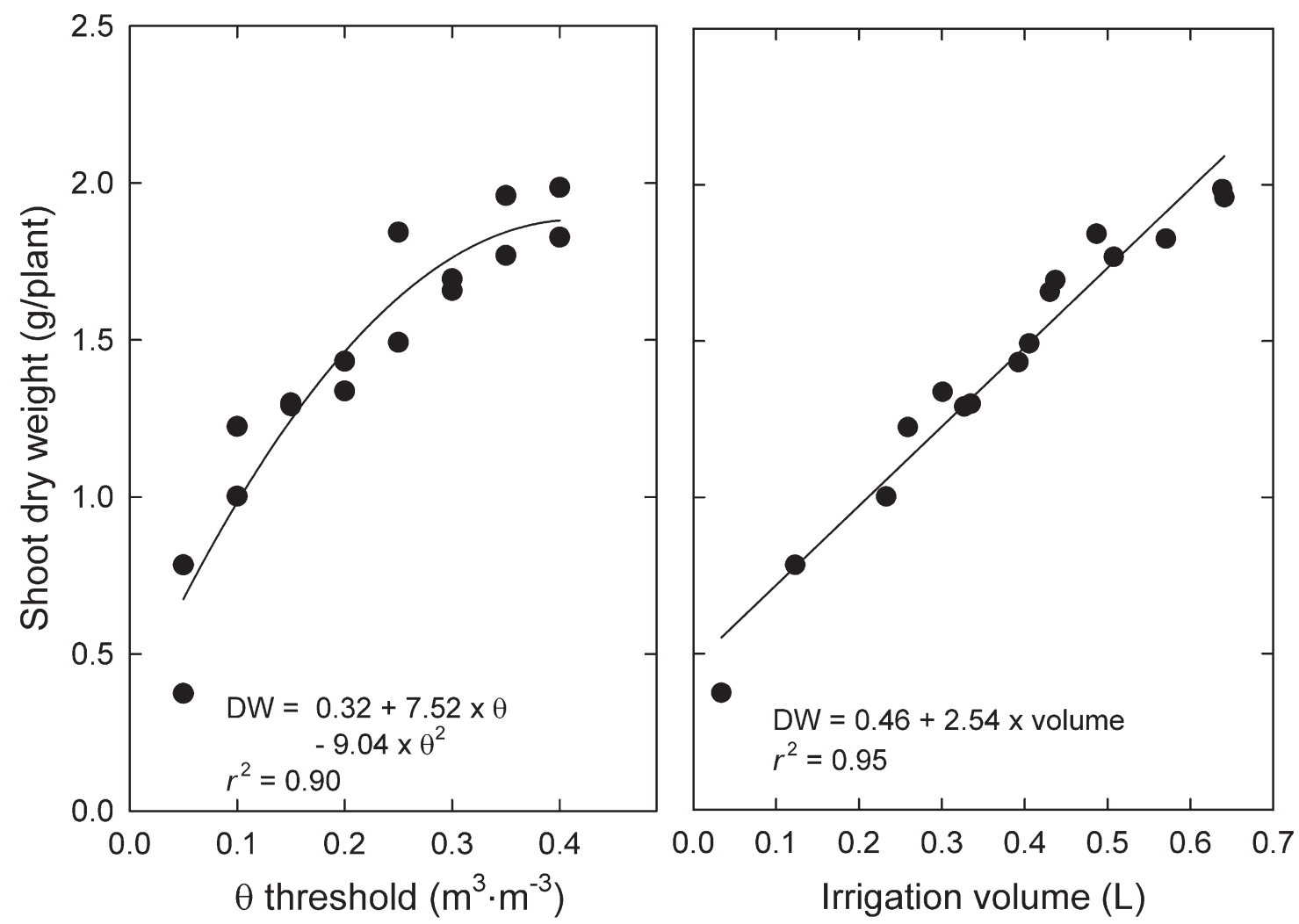

Fig. 5. Shoot dry weight (DW) of petunias irrigated with a soil moisture sensor-controlled automated irrigation system as a function of the substrate water content $(\theta)$ threshold (left) or total irrigation volume since the start of the irrigation treatments (right).

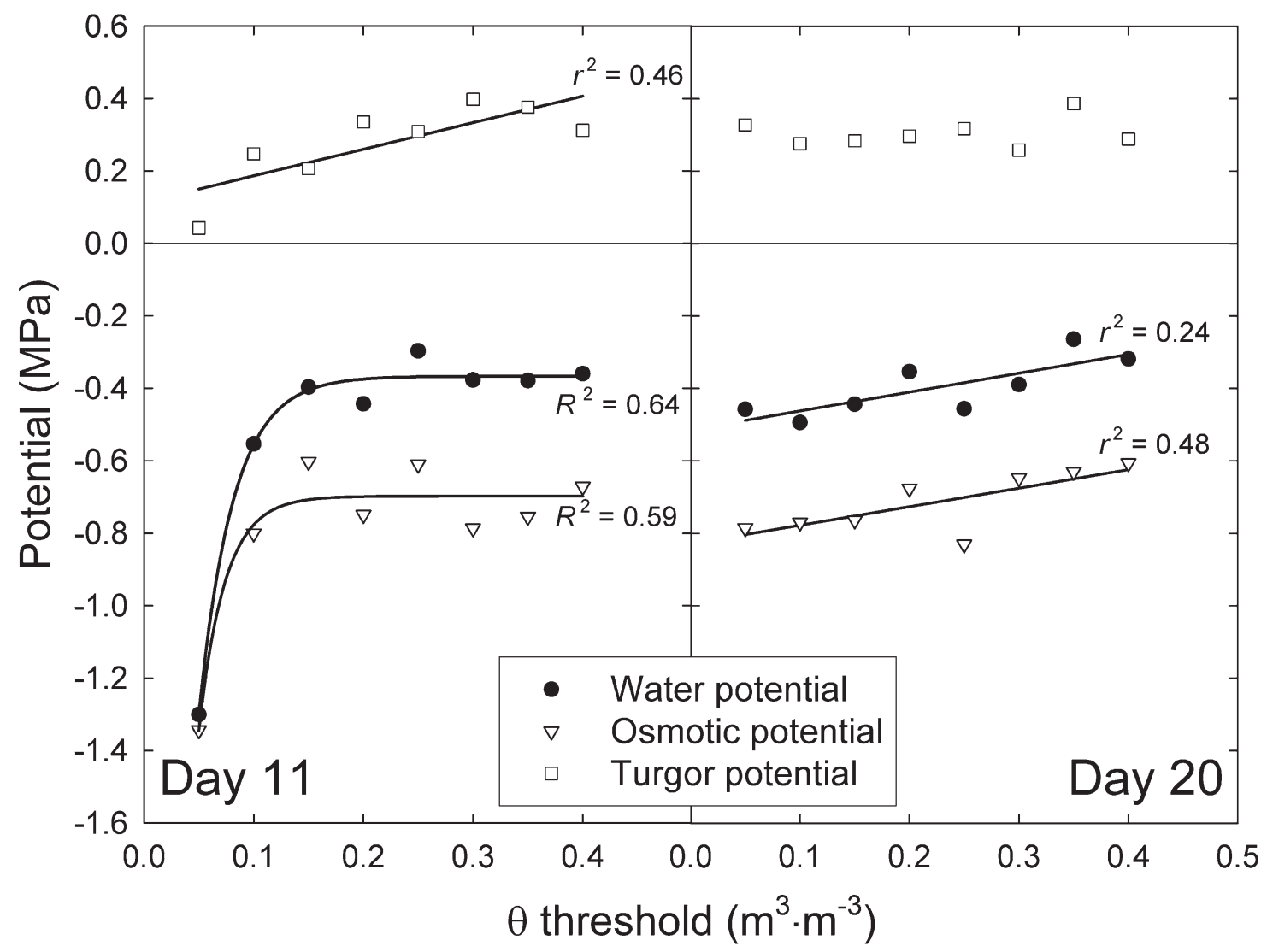

Fig. 6. Leaf water, osmotic, and turgor potential of petunias as affected by different substrate volumetric water contents $(\theta) 11$ and $20 \mathrm{~d}$ after treatment initiation. Curves indicate linear or exponential effects $(P<0.05)$. Note that it took $9 \mathrm{~d}$ for the substrate water content to drop to $0.05 \mathrm{~m}^{3} \cdot \mathrm{m}^{-3}$, so those plants had only been exposed to this low water level for only $2 \mathrm{~d}$ on Day 11. 
also decreased with decreasing $\theta$, whereas $\psi_{\mathrm{S}}$ and $\mathrm{P}$ were not measured in that study (Niu et al., 2007). When fully hydrated plants were measured at the end of the experiment (Day 22), $\psi, \psi_{\mathrm{S}}$, and $\mathrm{P}$ averaged $-0.32,-0.54$, and $0.23 \mathrm{MPa}$, respectively, without any treatment differences.

\section{Conclusions}

The soil moisture sensor-based irrigation control system was able to maintain $\theta$ close to the threshold. The total amount of irrigation water applied was closely correlated to the $\theta$ threshold. Daily irrigation volume of petunia in the plots with the highest $\theta$ ranged from 12 to $44 \mathrm{~mL} /$ plant and was correlated with plant age and DLI. Drought stress reduced petunia growth at $\theta$ thresholds below $0.25 \mathrm{~m}^{3} \cdot \mathrm{m}^{-3}$ and plant growth was strongly correlated to the total amount of water applied. This raises the prospect of using sensor-controlled irrigation as a method for growth control of ornamental plants. Petunias survived at all $\theta$ thresholds, although previous research has suggested that there is little or no plant-available water left in peat-based substrates at $\theta$ below 0.20 $\mathrm{m}^{3} \cdot \mathrm{m}^{-3}$. This finding suggests that it may be necessary to re-evaluate the value of substrate moisture release curves to predict water availability in soilless substrates.

\section{Literature Cited}

Blom-Zandstra, M. and K. Metselaar. 2006. Infrared thermometry for early detection of drought stress in Chrysanthemum. HortScience 41:136-142.

Briggs, J., T. Whitwell, M.B. Riley, and T. Lee. 1998. Cyclic irrigation and grass waterways combine to reduce isoxaben losses from container plant nurseries. J. Environ. Hort. 16:235238.

Burnett, S.E. and M.W. van Iersel. 2008. Morphology and irrigation efficiency of Gaura lindheimeri grown with capacitance-sensor controlled irrigation. HortScience 43:1555-1560.

Colla, G., Y. Rouphael, M. Cardarelli, S. Rinaldi, and E. Rea. 2009. Water use efficiency and transpiration of greenhouse geranium crop. Acta Hort. 807:271-276.

Fonteno, W.C. 1996. Growing media: Types and physical/chemical properties, p. 93-122. In: Reed, D.W. (ed.). Water, media and nutrition for greenhouse crops. Ball Publishing, Batavia, IL.

Howell, T.A. 2001. Enhancing water use efficiency in irrigated agriculture. Agron. J. 93:281-289.

Jones, H.G. 2004. Irrigation scheduling: Advantages and pitfalls of plant-based methods. J. Expt. Bot. 55:2427-2436.

Jones, H.G. 2007. Monitoring plant and soil water status: Established and novel methods revisited and their relevance to studies of drought tolerance. J. Expt. Bot. 58:119-130.

Jury, W.A. and H. Vaux. 2005. The role of science in solving the world's emerging water problems. Proc. Natl. Acad. Sci. USA 102:1571515720 .

Kacira, M., P.P. Ling, and T.H. Short. 2002 Establishing crop water stress index (CWSI) threshold values for early, non-contact detection of plant water stress. Trans. ASAE 45:775780 .

Kim, J. and M.W. van Iersel. 2009. Daily water use of abutilon and lantana at various substrate water contents. Proc. SNA Res. Conf. 54:1216.

Lea-Cox, J. and D.S. Ross. 2001. A review of the federal clean water act and the Maryland water quality improvement act: The rational for developing a water and nutrient management planning process for container nursery and greenhouse operations. J. Environ. Hort. 19:226-229.

Naasz, R., J.-C. Michel, and S. Charpentier. 2005. Measuring hysteretic hydraulic properties of peat and pine bark using a transient method. Soil Sci. Soc. Amer. J. 69:13-22.

Nemali, K.S., F. Montesano, S.K. Dove, and M.W. van Iersel. 2007. Calibration and performance of moisture sensors in soilless substrates: $\mathrm{ECH}_{2} \mathrm{O}$ and Theta probes. Scientia Hort. 112:227-234.
Nemali, K.S. and M.W. van Iersel. 2006. An automated system for controlling drought stress and irrigation in potted plants. Scientia Hort. 110:292-297.

Nemali, K.S. and M.W. van Iersel. 2008. Physiological responses to different substrate water contents: Screening for high water-use efficiency in bedding plants. J. Amer. Soc. Hort. Sci. 133:333-340.

Niu, G., D.S. Rodriguez, L. Rodriguez, and W. Mackay. 2007. Effect of water stress on growth and flower yield of Big Bend bluebonnet. HortTechnology 17:557-560.

Niu, G., D.S. Rodriguez, and Y.-T. Wang. 2006. Impact of drought and temperature on growth and leaf gas exchange of six bedding plant species under greenhouse conditions. HortScience 41:1408-1411.

Powell, C.C. and R.K. Lindquist. 1997. Ball pest and disease manual: Disease, insect, and mite control on flower and foliage crops. 2nd Ed. Ball Publishing, Batavia, IL.

Prenger, J.J., P.P. Ling, R.C. Hansen, and H.M. Keener. 2005. Plant response-based irrigation control system in a greenhouse: System evaluation. Trans. ASAE 48:1175-1183.

Starman, T. and L. Lombardini. 2006. Growth, gas exchange, and chlorophyll fluorescence of four herbaceous perennials during water stress conditions. J. Amer. Soc. Hort. Sci. 131:469-475.

Tyler, H.H., S.L. Warren, and T.E. Bilderback. 1996. Cyclic irrigation increases irrigation application efficiency and decreases ammonium losses. J. Environ. Hort. 14:194-198.

van Iersel, M., J.-G. Kang, and S.E. Burnett. 2007. Making greenhouse irrigation more efficient: Effects of substrate water content on the growth and physiology of vinca (Catharanthus roseus). Proc. SNA Res. Conf. 52:92-96.

Wallach, D. 2006. Evaluating crop models, p. 11-54. In: Wallach, D., D. Makowski, and J.W. Jones (eds.). Working with dynamic crop models: Evaluation, analysis, parameterization, and applications. Elsevier, Amsterdam, The Netherlands.

Wallach, R. 2008. Physical characteristics of soilless media, p. 41-116. In: Raviv, M. and J.H. Lieth (eds.). Soilless culture: Theory and practice. Elsevier, Amsterdam, The Netherlands. 